\title{
Effect of 1,4-Dioxane on histopathology of heart and muscles of Rabbit Oryctolagus cuniculus
}

\author{
Sadia Sidra Aziz ${ }^{1 *}$, Razia Iqbal ${ }^{1}$, Talhat Munir ${ }^{1}$, Izzah Butt ${ }^{1}$, Syeda \\ Iman Fatima ${ }^{1}$ and Haleema Zafar $^{1}$ \\ 1. Department of Zoology, Faculty of Science, University of Gujrat-Pakistan \\ *Corresponding author's email: sadia.sidra.aziz@gmail.com \\ Citation \\ Sadia Sidra Aziz, Razia Iqbal, Talhat Munir, Izzah Butt, Syeda Iman Fatima and Haleema Zafar. Effect of 1,4- \\ Dioxane on histopathology of heart and muscles of Rabbit Oryctolagus cuniculus. Pure and Applied Biology. \\ Vol. 10, Issue 3, pp628-633. http://dx.doi.org/10.19045/bspab.2021.100064
}

\begin{tabular}{llll}
\hline \hline Received: 11/08/2020 & Revised: 29/10/2020 & Accepted: 10/11/2020 & Online First: 24/11/2020 \\
\hline \hline
\end{tabular}

\section{Abstract}

1,4-Dioxane is used in numerous industries e.g. chemicals, pharmaceuticals, detergents, cosmetics, dyes, varnishes, paints, etc. Dioxane occurs frequently in industrial effluents, thus contaminating water bodies and the crops or fields irrigated with 1,4-dioxane contaminated water; and in routinely used synthetic products. It is known causative agent of tumors, cancer and adenomas in animals e.g. rats, mice, guinea pig. For this 45 -day study, 52 rabbits were taken and divided in 4 groups: A (control), B (1000mg per kg), C (1500mg per kg), and D (2000mg per kg). Impacts of dioxane on morphology and histopathology of heart, cardiac, smooth and skeletal muscles were studied on day 1, 15, 30 and 45. Lesions were observed around mouth and nose of treated animals. Tumor formation was detected in heart. Histopathological changes include disruption of tissue structure, necrosis, infiltration, invagination of outer tissue boundary and damaged cell structure. Current study provides clear evidence of toxicity and carcinogenicity of dioxane in rabbits.

Keywords: 1,4-Dioxane; Carcinogen; Heart; Histopathology; Muscles; Rabbits

\section{Introduction}

1,4-Dioxane is found naturally in vine ripped tomatoes and its products, fresh shrimps and brewed coffee [1]. It is employed as a solvent for numerous chemicals and is being used in many manufacturing industries e.g. chemical industry, detergents, pharmaceuticals, cosmetics, paints, varnishes, etc. [2]. In fact, it is estimated that dioxane is found as a contaminant in about one third of the cosmetics employing polyoxyethylene derivatives [3]. It contaminates many ground and surface water resources [4]. Chief sources of this water contamination include leakages, wastewater discharges, accidental spills, and via its solvent 1,1,1- trichloroethane (TCA) when disposed-off in soil. It doesn't bio-accumulate in food chains and is resistant to biodegradation [5].

Major modes of exposure to this chemical are oral, dermal and inhalation, the latter being the principal route [1]. Workers that are involved in its handling and manufacture face a greater hazard to get harmed because of repeated exposure. The extent of harm depends upon the length of exposure and concentration of chemical to which a person is exposed [6]. It is highly inflammable and forms explosives on exposure to air. Inside the human body, dioxane is metabolized into $\beta$ hydroxyethoxy acetic acid (HEAA). Other 
metabolites recognized in animal studies are 1,4-dioxan-2-one, diethylene glycol, $\beta$ hydroxyethoxyacetaldehyde, oxalic acids and carbon dioxide [1]. It is known for causing cancer, adenomas and tumor formation in some animals such as rats, guinea pig, mice, etc. [7].

Environmental Protection Agency of USA has categorized dioxane in Group B2 as probable human carcinogen $[1,8]$. The primary targets of dioxane are kidneys, eyes, liver, central nervous system (CNS), skin and respiratory passage ways. Respiratory tract and skin irritation, dehydration and cracking of skin are possible outcomes of frequent exposure. Depression of CNS, faintness, headache, drowsiness, unconsciousness, vomiting and coma can also be observed. Exposure to increased concentrations may cause injuries of liver and kidneys; and may prove to be fatal. Benign growths in liver and cancerous proliferations in abdominal cavity and nasal passage ways have been observed in laboratory rats [9]. Renal and hepatic lesions, edema of brain and demyelination were observed in humans due to poisoning caused by it [10]. This study aimed to elucidate the possible effects of dioxane on morphology and histopathology of tissues of heart, cardiac, smooth and skeletal muscles of rabbit.

\section{Materials and Methods}

The experiment was conducted on adult, healthy specimens of rabbits, weighing from $1-1.5 \mathrm{~kg}$; after seeking approval of ethical committee of University of Gujrat, Pakistan. They were given soaked bread, berseem hay, wheat straw, carrots, etc. in food. Experimental specimens were kept in separate cages, under controlled environment, i.e. 12-hour light and dark cycle and $23 \pm 2^{\circ} \mathrm{C}$ temperature. Specimens were vaccinated as precautionary measures. 52 rabbits were allocated into 4 groups A, $\mathrm{B}, \mathrm{C}$, and D (control, low, medium and high dose groups respectively), having 13 rabbits each. Specimens of treated groups were exposed to dioxane in the concentrations of $1000 \mathrm{mg} / \mathrm{kg}, 1500 \mathrm{mg} / \mathrm{kg}$ and $2000 \mathrm{mg} / \mathrm{kg}$ of body weight respectively. Treatment was continued up to 45 days. Dose was given orally by mixing it with food, once per day. Morphological and histopathological changes were observed at day 1, 15, 30 and 45 of experiment. Rabbits were slaughtered at random, three animals from each group; heart and muscles were removed, washed with water and kept in $0.085 \%$ saline solution to remove any impurity, grim or dust. Tissues were cut in small 4-5mm thick pieces and kept in Bouin's fluid for 8 hours. Tissues were processed for histopathological analysis according to standard procedure of microtomy; stained with eosin and hematoxylin and studied under microscope [11].

\section{Results}

Results were drawn at the end of experiment. Histopathological and morphological alterations were observed in tissues of afore mentioned organs. No alteration was found in specimens of group A as shown by (Fig. 1). No mortality was reported during the experiment. Histopathology of Group B, C and D indicated adverse effects of dioxane. Lesions were found around the mouth and nose of rabbits. Dioxane severely damages the studied organs, causing necrosis, thinning of outer wall, infiltration, damaged cell structure, invagination of epithelial layer, disrupted tissue structure along with lesion formation in tissues and invagination of outer boundary in stomach (Fig. 2). In skeletal muscles, disrupted tissue structure, lesion formation and necrosis were observed (Fig. 3). It causes damaged tissue structure, invagination and disruption of cell boundary, lesion formation in tissues, necrosis, and tumor formation in heart (Fig. 4). Similar observations were reported by Doursan et al., in 2013and Kano et al., in 2008 , in their study on rats and mice, by exposing them to various concentrations of dioxane $[12,13]$. 


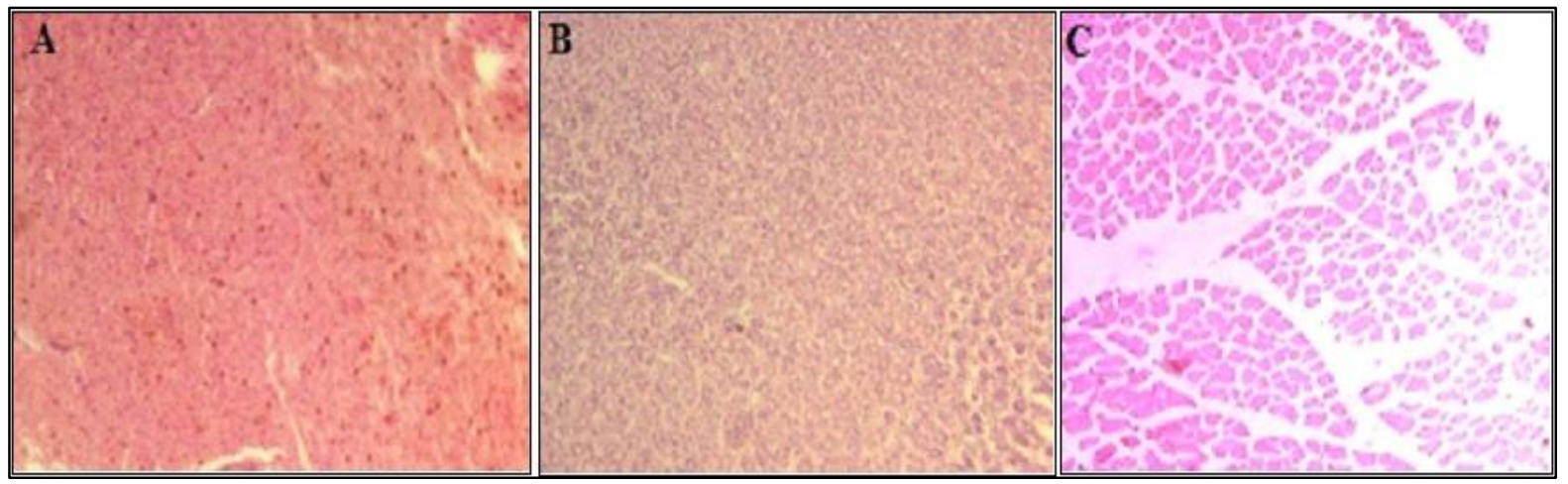

Figure 1. Normal histology of [A]: Heart, [B]: Stomach, [C]: Skeletal Muscles (H\&E Stain, LABOMED4X)

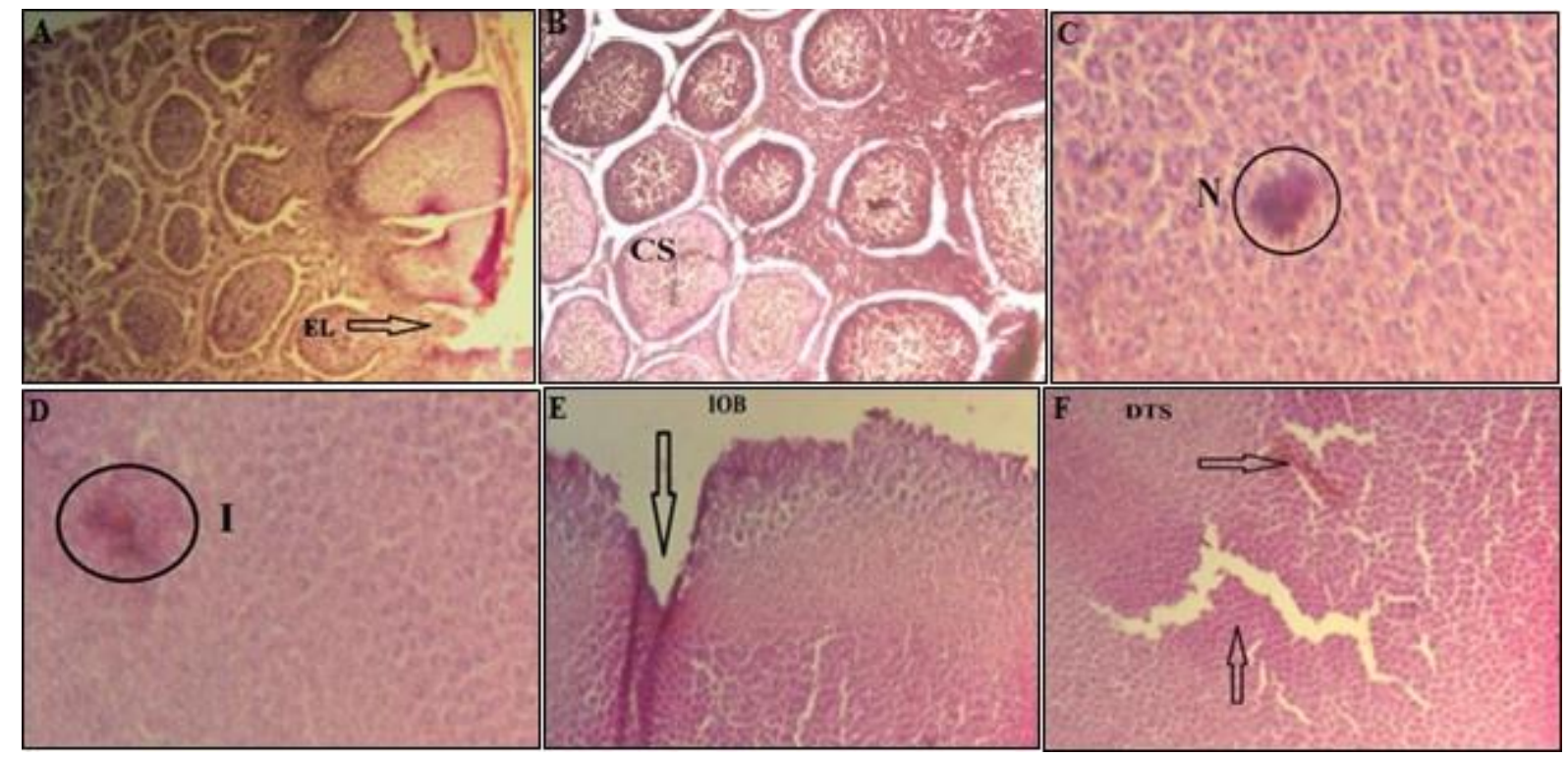

Figure 2. Effect of Dioxane on Histopathology of Stomach Showing [A]: Invagination of Epithelial Layer (EL), [B]: Damaged Cell structure (CS), [C]: Necrosis (N), [D]: Infiltration (I), [E]: Invagination of Outer Boundary (IOB), [F]: Damaged Tissue Structure (DTS) (H\&E Stain, LABOMED4X)

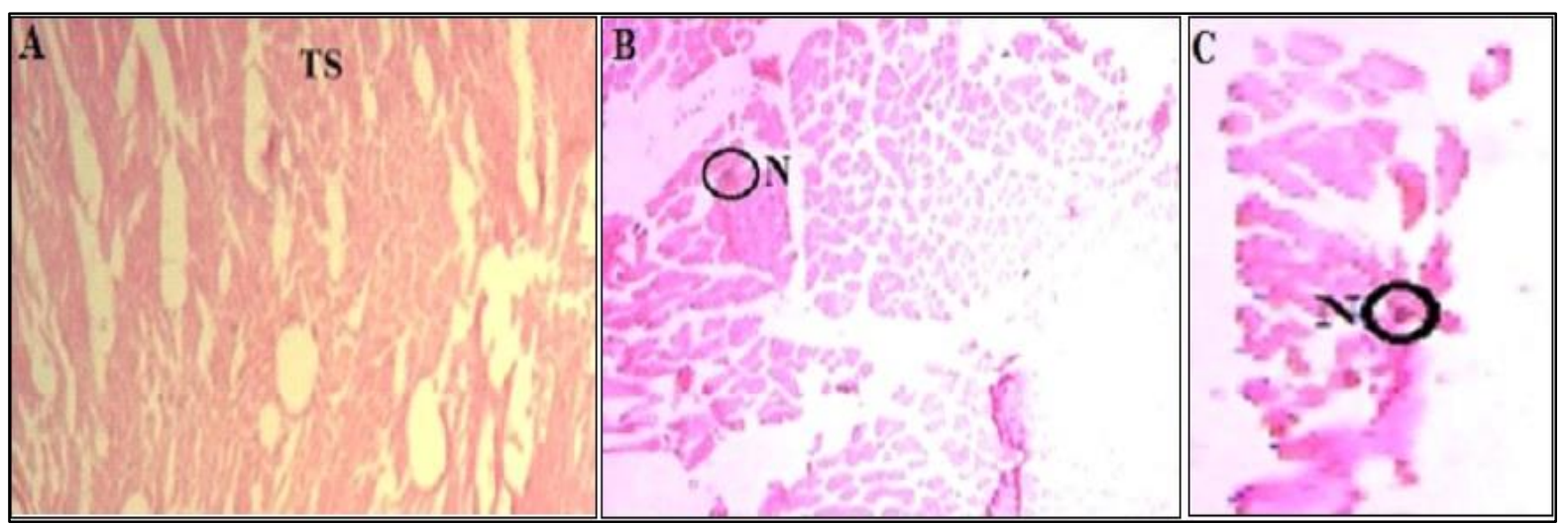

Figure 3. Effect of dioxane on histopathology of skeletal muscles showing [A]: Disrupted Tissue Structure (TS) and Lesion Formation, $[B, C]$ : Necrosis $(N)$ in the Tissues $(H \& E$ Stain, LABOMED4X) 

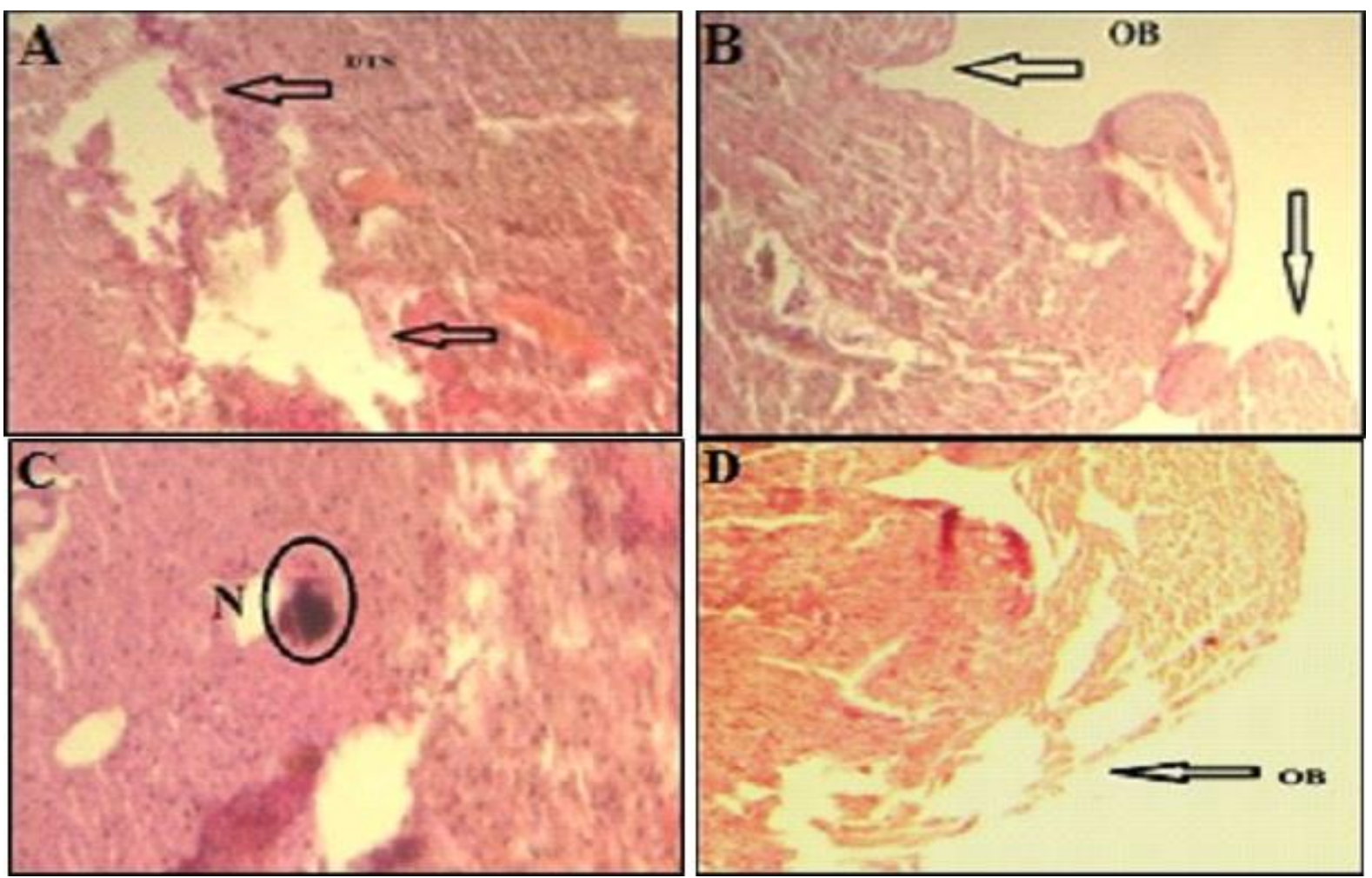

Figure 4. Effect of Dioxane on Histopathology of Heart Showing [A]: Disrupted tissue structure (DTS) and Lesion Formation, [B]: Invagination of Outer Boundary (OB), [C]: Necrosis (N), [D]: Disruption of Outer Boundary (OB) (H\&E Stain, LABOMED4X)

\section{Discussion}

Current study explains the dose-dependent and characteristically significant pronounced toxic effects of 1,4-dioxane shown in the form of alterations in the morphology and variations in the tissue structure e.g. necrosis, infiltration, damaged cell and tissue structure, damaged epithelial layer, invaginations of the outer boundaries, lesion formation in the tissues disturbing the intact arrangement of cells and leading to disrupted histological structures in the afore mentioned organs of rabbit, similar to the findings of Hashim et al. [14]. The tumors and carcinomas were characterized as malignant due to their marked invasion in adjacent normal tissues, also supported by Kasai et al. [6] where squamous cell carcinomas were found in the olfactory region. The results are in agreement with the reported findings that long-term oral administration of dioxane to rats induces squamous cell carcinomas [9, $15,16]$.
As 1,4-dioxane was delivered to experimental animals mixed with food, stomach morphology and tissues were severely affected by the direct gastrointestinal absorption of the chemical, especially in the high dosage group (group D). Dioxane was then transported to the heart by entering the bloodstream along with other nutrients and damaged the organ as shown by the necrosis and lesion formation and disrupted tissue boundaries, shown prominently in Group C and D. Dioxane was then transferred to the skeletal muscles via blood circulation where it caused lesion formation and necrosis. However, the damage in the skeletal muscles was less prominent as compared to the stomach and heart [13]. Disrupted tissue structure was most evident in heart where tissues were found severely damaged by the formation of lesions, especially in group D. In addition, increased cell death was observed in the form of degenerative necrotic adversaries with the increased dosage. The pronounced lesion formation 
and tumor formation observed in heart indicated the high probability of gastric and cardiac carcinogenicity, observed similarly by Ito et al., in 2000 in the liver cells [17].

\section{Conclusion}

Study concludes that dioxane causes severe damage to structure, morphology and histopathology of muscles and heart of rabbit on exposure to different concentrations. It is hazardous for our health, environment and animals. Analysis of crop, soil and water samples from waste disposal sites should be done. Further studies should be executed to examine dioxane-contaminated fodder samples on different herbivores. Intensive use of dioxane in industries should be prohibited. Use of different products containing dioxane as an impurity or constituent, should be limited.

\section{Authors' contributions}

Conceived and designed the experiments: SS Aziz \& R Iqbal, Performed the experiments: SS Aziz \& T Munir, Analyzed the data: I Butt \& SI Fatima, Contributed materials/ analysis/ tools: H Zafar, Wrote the paper: SS Aziz.

\section{Acknowledgment}

Authors are extremely grateful to ALLAH Almighty and Holy Prophet Muhammad (PBUH). Cordial gratitude is due towards supervisor Dr. Razia Iqbal, parents, all teachers and friends, especially my seniors Muhammed Hashim, Anum Ashiq and Ata ul Mustufa Fahid for their kind assistance and guidance. This research did not receive any specific grant from funding agencies in the public, commercial, or non-profit sectors.

\section{References}

1. DeRosa CT, Wilbur S, Holler J, Richter P \& Stevens WY (1996). Health evaluation of 1,4-dioxane. Toxicol Ind Health 12: 1-43.

2. Mori K, Nakamura Y, Kaneko M, Kan T, Amemiya T, Suzuki S \& Nakamura $\mathrm{H}$ (1992). Determination of 1,1,1trichloroethane and 1,4-dioxane in household aerosol products. Jpn $J$ Toxicol Environ Health 38: 511-516.
3. Wenninger JA (1980). Cosmetic safety issues-FDA research and regulatory programs. Assoc Food Drug Officials Q Bull 44: 145-152.

4. Lesage S, Jackson ER, Priddle WM \& Riemann GP (1990). Occurrence and fate of organic solvent residues in anoxic groundwater at the Gloucester Landfill, Canada. Environ Sci Technol 24: 559-566.

5. Burback BL \& Perry JJ (1993). Biodegradation and biotransformation of groundwater pollutant mixtures by Mycobacterium vaccae. Appl Environ Microbiol 59: 1025-1029.

6. Kasai T, Kano H, Umeda Y, Sasaki T, Ikawa N, Nishizawa T, Nagano K, Arito H, Nagashima H \& Fukushima $S$ (2009). Two-year inhalation study of carcinogenicity and chronic toxicity of 1,4-dioxane in male rats. Inhalation Toxicol 21(11): 889-897.

7. Argus MF, Sohal RS, Bryant GM, Hoch-Ligeti C \& Arcos JC (1973). Dose-response and ultrastructural alterations in dioxane carcinogenesis. Eur J Cancer 9: 237-243.

8. The Environmental Protection Agency of United States (1992). 1,4-Dioxane (1,4-Diethyleneoxide) Hazard Summary.

9. Hoch-Ligeti C, Argus MF and Arcos JE (1970). Induction of carcinomas in the nasal cavity of rats by dioxane. $\mathrm{Br}$ J Cancer 24: 164-167.

10. Berkely CA (1997). Determination of non-cancer chronic reference exposure levels. Office of Environmental Health Hazard Assessment.

11. Drury RAB \& Wallington EA (1980). In Carleton Histological Techniques. Oxford New York Toronto Oxford University Press 5: 40-67.

12. Doursan $M$, Reichard J, Nance $P$, Flayer BH, Parker A, Vincent M \& McConnell EE (2013). Mode of action analysis for liver tumors from oral 1,4dioxane exposures and evidence-based dose response assessment. 68(3): 387401. 
13. Kano H, Umeda Y, Saito M, Senoh H, Ohbayashi H, Aiso S, Yamazaki K, Nagano K \& Fukushima S (2008). Thirteen-week oral toxicity of 1,4dioxane in rats and mice. $J$ Toxicol Sci 33(2): 141-153.

14. Hashim M, Iqbal R, Afsheen S, Fahad MUA, Asghar U, Daman M \& Ghazanfar M (2018). Effect of 1,4dioxane on rabbit (Oryctolagus cuniculus) reproductive hormonal level and histopathology of testes and ovaries. Pure Appl Biol 7(2): 466-469.

15. Kociba RJ, McCollister SB, Park C \& Torkelson TR (1974). 1,4-Dioxane-I. Results of a 2-year ingestion study in rats. Toxicol Appl Pharmacol 30: 275286.

16. Yamazaki K, Ohno H, Asakura M, Narumi A, Ohbayashi H, Fujita H, Ohnishi M, Katagiri T, Senoh H, Yamanouchi K, Nakayama E, Yamamoto S, Noguchi T, Nagano K, Enomoto M \& Sakabe H (1994). Twoyear toxicological and carcinogenesis studies of 1,4-dioxane in F344 rats and BDF1 mice- Drinking studies. Proc of the second Asia-Pacific Symp on Environ and Occup Health 193-198.

17. Ito N, Imaida K \& Asamoto M (2000). Early detection of carcinogenic substances and modifiers in rats. Mutat Res 462: 209-217. 